\title{
MINAT INVESTOR MUDA UNTUK BERINVESTASI DI PASAR MODAL MELALUI TEKNOLOGI FINTECH
}

Ferdinand J. Tumewu

Universitas Sam Ratulangi

\author{
A R T I C L E I N F O
}

Keywords: Intention, Young

Investors, Investatio, Capital

Market, Financial Technology

Kata Kunci: Minat berinvestasi, investor muda, investasi, pasar modal, Finansial Teknologi
Abstract: Investment is one of the factors that drive the economic growth of a region, which is beneficial to improve the economy, create equity, reduce poverty and increase regional and individual prosperity. The importance of this investment needs to be continued to be socialized especially to the younger generation and millennial generation so that in the future these young people can enjoy prosperity and help the regional and national economy. The problems faced include the lack of young people who invest and participate to invest, especially in the capital market. In addition, with the development of digital technology and industry 4.0 creating fintech technology to invest, but there are still less young generation to utilize this fintech technology to invest in the capital market. This study aims to examine the factors that influence the interests of young investors to invest in the capital market by utilizing fintech technology. Samples were taken from the younger generation in the city of Manado with a total sample of 100 respondents spread in the city of Manado. Data analysis using quantitative analysis by testing the hypothesis of the respondents' perceptions. The research results have implications for increasing the number of young people who are interested in investing in the capital market through fintech technology in North Sulawesi.

Abstrak: Investasi merupakan salah satu faktor yang mendorong pertumbuhan ekonomi suatu wilayah, yang bermanfaat meningkatkan perekonomian, menciptakan pemerataan, mengurangi kemiskinan dan meningkatkan kemakmuran daerah dan individu. Pentingnya investasi ini perlu diterus disosialisasikan khususnya kepada para generasi muda dan generasi milenial agar di masa depan para generasi muda ini bisa menikmati kemakmuran dan membantu perekonomian daerah dan nasional. Permasalahan yang dihadapi antara lain masih kurangnya generasi muda yang berinvestasi serta berpartisipasi untuk berinvestasi khususnya di pasar modal. Selain itu dengan perkembangan teknologi digital dan industri 4.0 menciptakan teknologi fintech untuk berinvestasi, namun masih kurang generasi muda untuk memanfaatkan teknologi fintech ini untuk berinvestasi di pasar modal. Penelitian ini bertujuan untuk meneliti faktor yang mempengaruhi minat investor muda untuk berinvestasi di pasar modal dengan memanfaatkan teknologi fintech. Sampel diambil dari generasi muda di Kota Manado dengan jumlah sampel sebanyak 100 responden yang tersebar di Kota Manado. Analisis data menggunakan analisis kuantitatif dengan melakukan uji hipotesis terhadap persepsi para responden. Hasil penelitian berimplikasi pada peningkatan jumlah generasi muda yang berminat untuk berinvestasi di pasar modal melalui teknologi fintech di Sulawesi Utara. 


\section{PENDAHULUAN}

\section{Latar Belakang}

Pengetahuan fundamental tentang investasi merupakan hal sangat penting untuk diketahui oleh calon investor. Ini bertujuan agar investor terhindar dari praktik-praktik investasi yang tidak rasional, budaya ikutikutan, penipuan, dan resiko kerugian. Diperlukan pengetahuan yang cukup, pengalaman serta naluri bisnis untuk menganalisis efek-efek mana yang akan dibeli dalam melakukan investasi di pasar modal (Pajar, 2017). Pengetahuan yang memadai akan cara berinvestasi yang benar amat diperlukan guna menghindari terjadinya kerugian saat berinvestasi misalnya di pasar modal antara lain melalui instrumen investasi saham khususnya financial technology (fintech) atau teknologi finansial yang mempermudah dan mempercepat investasi.

Fintech merupakan industri yang berkembang yang menggunakan teknologi untuk meningkatkan aktivitas di bidang finansial (Schueffel, 2016). Pemanfaatan telepon cerdas untuk perbankan bergerak, untuk layanan investasi dan mata uang digital adalah contoh dari teknologi yang ditujukan untuk membuat layanan finansial yang bisa dapat diakses oleh masyarakat luas (Sanicola, 2017). Investasi fintech di Eropa di tahun 2014 telah mencapai AS \$1,5 miliar, dimana perusahaan berbasis di Inggris berinvestasi sebesar AS\$539 juta, perusahaan berbasis di Belanda berinvestasi sebesar AS\$306 juta, serta perusahaan berbasis di Swedia berinvestasi sebesar AS\$266 juta untuk fintech.

Pertumbuhan investor di pasar modal Indonesia dinilai cukup baik. Namun apabila dibandingkan dengan negara lain, animo masyarakat di Indonesia untuk untuk berinvestasi terbilang masih cukup rendah, yaitu berjumlah hanya sekitar $0,15 \%$ penduduk Indonesia, sedangkan penduduk Malaysia berjumlah sekitar 15\%, Singapura 30\% dan Australia $30 \%$ (Pajar, 2017). Berdasarkan data Otoritas Jasa Keuangan di Indonesia, jumlah rekening efek saat ini masih kecil sekali yaitu kurang dari 600.000 rekening dibandingkan dengan Thailand yang telah mencapai 25 juta rekening. PT Bursa Efek Indonesia (BEI) mencatat jumlah investor lewat Single Investor Identification (SID) telah mencapai 494 ribu per 22 Agustus 2016. Angka investor tersebut mengalami kenaikan tiap bulannya. Per tanggal 10 Agustus 2016, Bursa Efek Indonesia merilis data jumlah perusahaan Indonesia yang berhasil Go Public yakni berjumlah sebanyak 517. Banyaknya perusahaanperusahaan baru dapat menjadi salah satu faktor pendorong jumlah investor, terutama pada investasi saham di pasar modal. Akan tetapi, banyaknya jumlah perusahaan saja tidak akan berpengaruh signifikan terhadap pertumbuhan jumlah investor apabila kesadaran akan investasi dari masyarakat itu sendiri masih rendah. OJK pada tahun 2013 melakukan survei mengenai tingkat literasi pehamaman akan keuangan. Hasil survei yang didapapati OJK menunjukan bahwa hanya sekitar 21,8\% dari 9.000 responden di seluruh Indonesia, artinya masih kecil orang Indonesia yang paham akan keuangan. Meskipun terhitung jumlah investor di pasar modal tiap tahunnya bertambah, namun berdasarkan data yang dirilis Kustodian Sentral Efek Indonesia (KSEI) melaporkan bahwasanya berdasarkan kepemilikan, total aset saham hingga 29 Juli 2016 masih didominasi oleh investor asing (Sakina, 2016, dalam Pajar, 2017).

Negara indonesia merupakan negara yang sedang berkembang dimana orientasi secara finansial masyarakatnya masih berjangka pendek atau dalam kategori saving society (menabung). Bila dibandingkan dengan negara maju orientasinya lebih ke jangka panjang atau dalam kategori investing society (investasi). Kesadaran akan pengelolaan keuanggan mereka sudah sedemikian besarnya hingga mampu menyisihkan 30\% pendapatannya untuk investasi. Oleh karena itu, diperlukan edukasi publik yang intensif dan berkelanjutan guna mengubah masyarakat dari saving society ke investing society (Ari, 2009, dalam Pajar, 2017). Edukasi yang dilakukan secara bertahap diharapkan mampu membangun motivasi masyarakat untuk beralih dari menabung menjadi berinvestasi. 
Berdasarkan survei yang dilakukan BEI, Nielsen, dan Universitas Indonesia, diketahui bahwa usia muda berpotensi besar menjadi investor saham. Dari hasil studi tersebut ternyata pemilikan saham mulai menjadi bagian gaya hidup masyarakat (Rezza, 2016). Tren dalam membeli barang-barang mewah dan bermerek untuk dijadikan instrumen investasi mulai menyurut. Belakangan ini, publik kembali melirik investasi di pasar modal melalui share saving. Hal ini tak lepas dari gerakan kampanye yang dilakukan oleh PT Bursa Efek Indonesia (BEI).

Salah satu yang menjadi obyek sasaran utama PT Bursa Efek Indonesia (BEI) dalam menjaring investor- investor baru adalah dengan mendirikan Galeri Investasi yang ada di setiap Universitas. Direktur Pengembangan BEI Nicky Hogan (Pajar, 2017) menyatakan, mahasiswa dapat menjadi potensi besar sebagai investor pasar modal baru. Hal ini dapat terwujud dengan semakin bertambah banyaknya Galeri Investasi yang dibangun. Dengan demikian jumlah investor baru dari kalangan mahasiswa juga semakin meningkat. Walaupun belum punya pendapatan tetap, tapi minat dari mahasiswa untuk berinvestasi cukup tinggi. Lebih banyak mahasiswa sebenarnya karena pembukaan galeri investasi kita hampir setiap minggu ada pembukaan 1 galeri investasi. Biasanya dibarengi dengan kegiatan seminar di mana mahasiswa mencatatkan diri sebagai investor baru (Nicky Hogan, 2016, dalam Pajar, 2017). Hal ini menunjukan besarnya partispasi generasi muda khususnya mahasiswa dalam berinvestasi.

Tujuan Penelitian Ini Adalah Untuk Menganalisis faktor-faktor yang mempengaruhi minat investor muda untuk berinvestasi di pasar modal melalui teknologi fintech di Sulawesi Utara. Minat disini lebih kepada minat berbentuk kesadaran untuk melakukan investasi.

\section{Tujuan Penelitian}

Tujuan Penelitian ini adalah untuk

1. Untuk mengetahui pengaruh financial literacy, personal interest, dan environment terhadap minat berinvestasi online.

2. Untuk mengetahui pengaruh financial literacy terhadap minat berinvestasi online.

3. Untuk mengetahui pengaruh personal interest terhadap minat berinvestasionline.

4. Untuk mengetahui pengaruh environment terhadap minat berinvestasi online.

\section{TINJAUAN PUSTAKA}

\section{Investasi}

Menurut Tandelilin, (2012), "investasi adalah komitmen atas sejumlah dana atau sumber daya lainnya yang dilakukan pada saat ini, dengan tujuan memperoleh sejumlah keuntungan di masa yang akan datang". Pengertian investasi menurut Kamarudin, (2009), yaitu "menempatkan uang atau dana dengan harapan untuk memperoleh tambahan atau keuntungan tertentu atas uang atau dana tersebut". Pengertian Investasi menurut Ikatan Akuntan Indonesia dalam "Standar Akuntansi Keuangan "(Ikatan Akuntan Indonesia, 2015), yaitu suatu aset yang digunakan perusahaan untuk pertumbuhan kekayaan (accretion of wealth) melalui distribusi hasil investasi (seperti bunga, royalti, dividen dan uang sewa), untuk apresiasi nilai investasi, atau untuk manfaat lain bagi perusahaan yang berinvestasi seperti manfaat yang diperoleh melalui hubungan perdagangan. Menurut Salim \& Sutrisno, (2008) investasi ialah penanaman modal yang dilakukan oleh investor, baik investor asing maupun domestik dalam berbagai bidang usaha yang terbuka untuk investasi, yang bertujuan untuk memperoleh keuntungan. Dari pengertian di dapat dinyatakan bahwa investasi adalah sejumlah dana atau sumber dana lainnya yang digunakan perusahaan untuk pertumbuhan 
kekayaan melalui distribusi hasil investasi berupa bunga, royalti dan dividen dengan harapan untuk memperoleh tambahan atau keuntungan atas dana tersebut di masa yang akan datang.

Investasi pada dasarnya merupakan penempatan sejumlah dana pada saat ini dengan tujuan untuk memperoleh sejumlah keuntungan di masa yang akan datang. Investasi dapat diartikan sebagai komitmen untuk menanamkan sejumlah dana pada saat ini dengan tujuan memperoleh keuntungan di masa datang (Herlianto, 2013).

Investasi dapat memiliki tiga aspek sebagai berikut, yaitu (Soemitra, 2014):

1. Aspek uang (yang ditanamkan) dan (yang diharapkan), sehingga untuk menilai (kekayaan) yang akan datang. Maka untuk menilai (kelayakan) investasi digunakan juga konsep uang.

2. Aspek waktu (sekarang dan masa yang akan datang) oleh karena itu untuk menilai investasi juga digunakan aspek waktu.

3. Aspek manfaat. Dari aspek manfaat ini maka penilaian kelayakan investasi juga harus melihat manfaat dan biaya yang ditimbulkannya dengan menggunakan azas manfaat atau cost benefit ratio.

Terdapat dua tipe investasi yaitu (Bandi \& Hartono, 2000):

1. Investasi Langsung Investasi ini berupa pembelian langsung aktiva keuangan suatu perusahaan. Investasi langsung dapat dilakukan pada:

a. Pasar uang (money market), berupa aktiva yang mempunyai risiko gagal kecil, jatuh tempo pendek dengan tingkat cair yang tinggi seperti Treasury bill (T-bill).

b. Pasar modal (capital market), berupa surat-surat berharga pendapatan tetap (fixed-income securities) dan saham-saham (equity income).

c. Pasar turunan (deverative market), berupa opsi (option) dan futures contract.

2. Investasi Tidak Langsung Investasi tidak langsung merupakan pembelian saham dari perusahaan investasi yang mempunyai portofolio aktiva-aktiva keuangan dari perusahaan lain. Perusahaan investasi adalah perusahaan yang menyediakan jasa keuangan dengan cara menjual sahamnya kepada publik dan menggunakan dana yang diperoleh untuk diinvestasikan ke dalam portofolionya. Proses investasi terdiri dari lima tahap yaitu (Bandi \& Hartono, 2000):

1. Penentuan tujuan investasi. Tujuan investor antara yang satu dengan yang lain tidak sama, tergantung dari keputusan yang dibuat.

2. Penentuan kebijakan investasi. Tahap ini merupakan tahap penentuan kebijakan untuk memenuhi tujuan investasi yang telah ditetapkan.

3. Pemilihan strategi portofolio. Ada dua strategi yang dipilih, yaitu strategi portofolio aktif dan strategi portofolio pasif. Strategi portofolio aktif meliputi penggunaan informasi yang tersedia dan teknik-teknik peramalan secara aktif untuk mencari kombinasi portofolio yang lebih baik. Strategi portofolio pasif meliputi aktivitas investasi pada portofolio yang seiring dengan kinerja indek pasar.

4. Pemilihan asset. Tahap ini merupakan proses pengevaluasian setiap sekuritas yang ingin dimasukan dalam portofolio.

5. Pengukuran dan evaluasi kinerja portofolio. Tahap ini meliputi kinerja portofolio dan pembandingan hasil pengukuran tersebut dengan kinerja

\section{Minat}

Menurut H.C. Witherington yang dikutip Arikunto (2012), "Minat adalah kesadaran seseorang terhadap suatu objek, suatu masalah atau situasi yang mengandung kaitan dengan dirinya." Batasan ini lebih memperjelas pengertian minat tersebut dalam kaitannya dengan perhatian seseorang. Perhatian adalah pemilihan suatu perangsang dari sekian banyak perangsang yang dapat menimpa mekanisme penerimaan seseorang. Orang, masalah atau situasi tertentu adalah perangsang yang datang pada mekanisme penerima seseorang, karena pada suatu waktu tertentu hanya satu perangsang yang dapat disadari. Maka dari sekian banyak perangsang tersebut 
harus dipilih salah satu. Perangsang ini dipilih karena disadari bahwa ia mempunyai sangkut paut dengan seseorang itu. Kesadaran yang menyebabkan timbulnya perhatian itulah yang disebut minat. Berdasarkan pengertian dimuka maka unsur minat adalah perhatian, rasa senang, harapan dan pengalaman (Arikunto, 2012).

Pengertian Minat menurut Winkel, (2009) adalah "kecenderungan yang menetap dalam subyek untuk merasa senang dan tertarik pada bidang atau hal tertentu dan merasa senang berkecimpung dalam bidang itu". Sedangkan Menurut Hurlock dalam Timothi menyatakan bahwa "minat seseorang dapat ditumbuhkan dengan memberikan kesempatan bagi orang tersebut untuk belajar mengenai hal yang dia inginkan".

Minat merupakan suatu dorongan yang kuat dalam diri seseorang terhadap sesuatu. Minat adalah rasa lebih suka dan ketertarikan pada suatu hal atau aktivitas, tanpa ada yang menyuruh (Winkel, 2009). Keinginan seseorang akan sesuatu menimbulkan kegairahan terhadap sesuatu tersebut. Minat dapat timbul dengan sendirinya, yang diawali dengan adanya rasa suka terhadap sesuatu.

Jenis-Jenis Minat Menurut banyak ahli mengemukakan mengenai jenis jenis minat. Menurut Carl safran (dalam Sukardi, 2003) mengklasifikasikan minat menjadi empat jenis :

1. Expressed interest adalah minat yang diekspresikan melalui suatu objek aktivitas.

2. Manifest interest adalah minat yang disimpulkan dari keikutsertaan individu pada suatu kegiatan tertentu.

3. Tested interest adalah minat yang berasal dari pengetahuan dan keterampilan suatu kegiatan.

4. Invored interest dimana minat ini berasal dari daftar aktivitas dan kegiatan yang sama dengan pernyataan.

\section{Penelitian Terdahulu}

Penelitian Azhar et al (2017). Penelitian ini menggunakan data primer dengan kuesioner, dan sampel yang dipilih adalah generasi muda berusia 18 hingga 28 tahun. Berdasarkan bacaan kami dalam literatur kesadaran, ada tiga variabel independen yang diidentifikasi; literasi keuangan, minat pribadi, dan lingkungan yang berhubungan dengan variabel dependen, kesadaran investasi. Tujuan dari ini adalah untuk memeriksa kesadaran hubungan dan variabel independen yang disebutkan sebelumnya. Hasilnya mengungkapkan bahwa kunci yang didorong oleh investasi di kalangan generasi muda secara signifikan didasarkan pada variabel independen yang dipilih. Akhirnya, batasan dan rekomendasi dimasukkan untuk membantu peneliti lebih lanjut untuk mendapatkan hasil yang lebih baik.

Penelitian Susanti et al (2018). Penelitian ini bertujuan untuk mengetahui pengaruh faktor pribadi, faktor psikologi dan factor sosial terhadap minat mahasiswa dalam berinvestasi di Galeri Investasi Universitas Negeri Makassar. Objek penelitian ini adalah mahasiswa yang terdaftar sebagai anggota di galeri investasi Universitas Negeri Makassar. Populasi penelitian ini adalah sebanyak 86 mahasiswa yang terdaftar sebagai anggota di galeri investasi Universitas Negeri Makassar. Sampel yang diambil sebanyak 46 orang mahasiswa. Teknik analisis data yang digunakan adalah regresi linear melalui program SPSS 24. Hasil penelitian menunjukkan bahwa faktor individu, faktor psikologis dan sosial secara simultan memiliki pengaruh signifikan terhadap minat mahasiswa berinvestasi, sedangkan secara persial hanya faktor psikologis yang memiliki pengaruh signifikan terhadap minat mahasiswa berinvestasi di Galeri Investasi Universitas Negeri Makassar. 


\section{Model Penelitian}

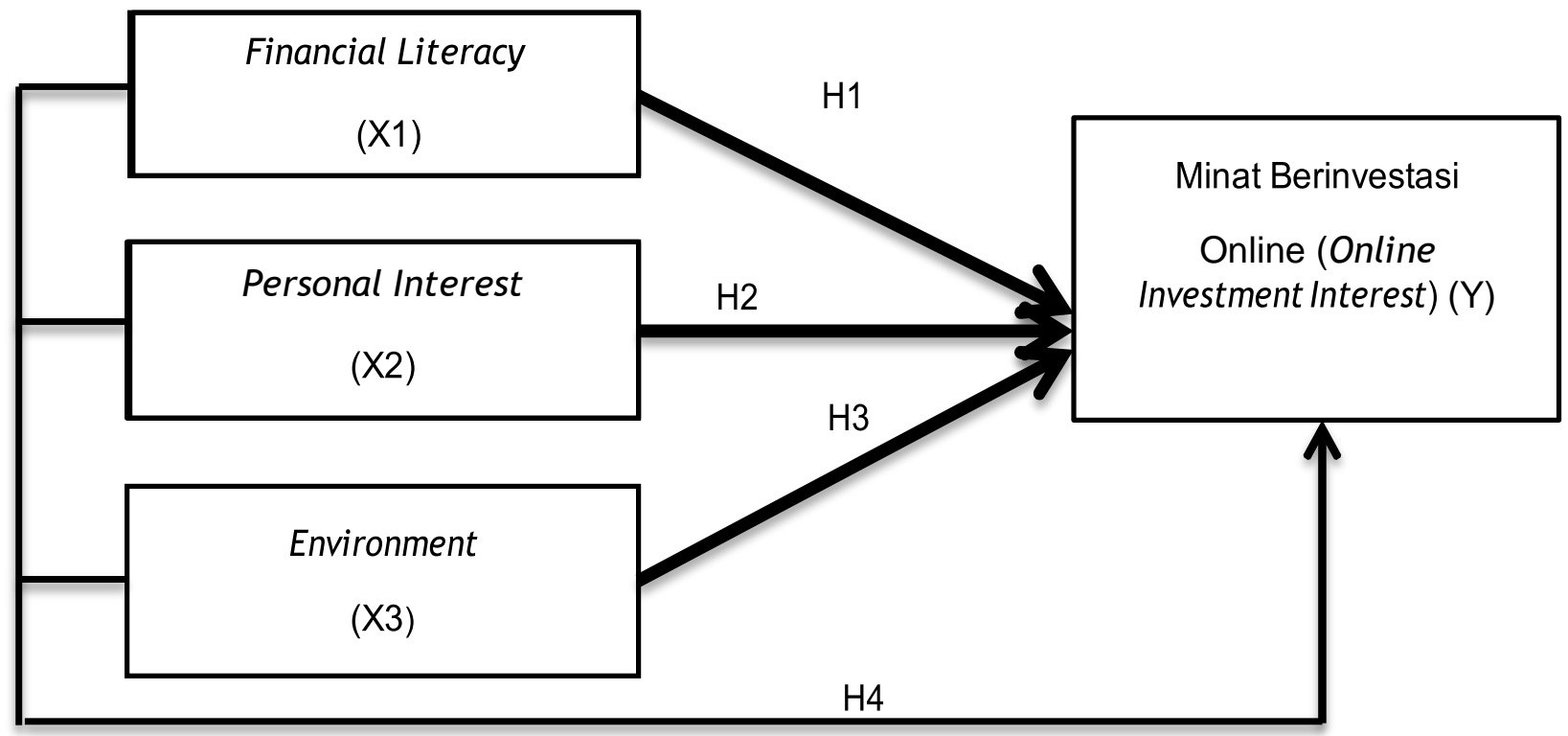

Gambar 1 Kerangka Pemikiran

Sumber: Kajian Teori, 2019

\section{Hipotesis Penelitian}

Hipotesis dalam penelitian ini sebagai berikut:

H1: Diduga financial literacy, personal interest, dan environment berpengaruh terhadap minat berinvestasi online.

H2: Diduga financial literacy berpengaruh terhadap minat berinvestasi online.

H3: Diduga personal interest berpengaruh terhadap minat berinvestasi online.

H4: Diduga environment berpengaruh terhadap minat berinvestasi online.

\section{METODE PENELITIAN}

\section{Pendekatan Penelitian}

Pendekatan penelitian merupakan merupakan cara berpikir yang diadopsi peneliti tentang bagaimana desain riset dibuat dan bagaimana penelitian akan dilakukan. Penelitian ini merupakan penelitian kuantitatif berupa uji hipotesis hubungan antar variabel.

\section{Populasi, Sampel, dan Teknik Sampling}

Untuk keperluan survei, jumlah sampel yang diambil adalah sekitar 100 responden yaitu generasi muda di Manado. Penarikan sampel adalah purposive sampling. Kriteria penelitian adalah: pemuda berusia antara 1535 tahun, sering menggunakan smartphone dalam beraktivitas, mengetahui tentang pasar modal, mengetahui sedikit tentang fintech. 


\section{Jenis dan Sumber Data}

Jenis data penelitian adalah data kuantitatif yaitu jenis data yang dapat diukur atau dihitung secara langsung, yaitu berupa informasi atau penjelasan yang dinyatakan dalam bentuk bilangan atau angka. Selanjutnya sumber data antara lain data primer yaitu data dari sumber pertama atau sumber primer, serta data sekunder yang dikumpulkan peneliti sebagai penunjang dari sumber pertama serta berbentuk dokumen dan artikel.

\section{Teknik Pengumpulan Data}

Teknik pengumpulan data pada penelitian ini menggunakan pendekatan kuantitatif yang kemudian didukung oleh penelitian kualitatif. Pendekatan kuantitatif dilakukan dengan melakukan survey kepada generasi muda di Manado.

\section{Definisi Operasional Variabel}

Tabel 1. Definisi Operasional Variabel dan Indikator Variabel Penelitian

\begin{tabular}{|c|c|c|c|}
\hline Variabel & $\begin{array}{c}\text { Pengertia } \\
n\end{array}$ & Skala & Sumber \\
\hline $\begin{array}{l}\text { Financial } \\
\text { Literacy }\end{array}$ & $\begin{array}{l}\text { kemampuan untuk membaca, menafsirkan, dan } \\
\text { menganalisis, mengelola uang, berkomunikasi tentang } \\
\text { kondisi keuangan pribadi yang memengaruhi kesejahteraan } \\
\text { materi, menghitung, mengembangkan penilaian } \\
\text { independen, dan mengambil tindakan yang dihasilkan dari } \\
\text { proses tersebut untuk berkembang di dunia } \\
\text { keuangan kita yang kompleks }\end{array}$ & $\begin{array}{l}\text { Likert } \\
5 \text { point }\end{array}$ & $\begin{array}{l}\text { (Azhar } \text { et al., } \\
\text { 2017) }\end{array}$ \\
\hline Personal Interest & $\begin{array}{l}\text { Minat pribadi seseorang untuk mengambil keputusan terkait } \\
\text { produk finansial }\end{array}$ & $\begin{array}{l}\text { Likert } 5 \\
\text { point }\end{array}$ & $\begin{array}{l}\text { (Azhar et al., } \\
\text { 2017) }\end{array}$ \\
\hline Environment & Lingkungan dari individu untuk berinvestasi & $\begin{array}{l}\text { Likert } 5 \\
\text { point }\end{array}$ & $\begin{array}{l}\text { (Azhar et al., } \\
\text { 2017) }\end{array}$ \\
\hline $\begin{array}{l}\text { Minat } \\
\text { Berinvestasi } \\
\text { Online }\end{array}$ & Kecenderungan individu untuk berinvestasi secara online & $\begin{array}{l}\text { Likert } 5 \\
\text { point }\end{array}$ & $\begin{array}{l}\text { (Azhar et al., } \\
\text { 2017) }\end{array}$ \\
\hline
\end{tabular}

Sumber: Data Olahan

\section{Teknik Analisis Data}

Model Regresi didasarkan pada hubungan fungsional ataupun kausal variabel independen dengan variabel dependen (Ghozali, 2013). Analisis regresi linear berganda diuji menggunakan program SPSS versi 23. Model analisis regresi linear berganda yang digunakan untuk menguji hipotesis adalah sebagai berikut:

$$
\mathbf{Y}=\mathbf{a}+\boldsymbol{\beta 1 X} \mathbf{X}+\boldsymbol{\beta 2} \mathbf{X} 2+\beta 3 X_{3}+\varepsilon t
$$

Keterangan:

$\begin{array}{lll}\text { a } & : & \text { Nilai konstanta } \\ \boldsymbol{\beta 1}, 2,3 & : & \text { Angka arah koefisien regresi } \\ & : & \text { Residual } \\ \mathrm{Y} & : & \text { Minat berinvestasi online } \\ \mathrm{X} 1 & : & \text { Financial literacy } \\ \mathrm{X} 2 & : & \text { Personal interest } \\ \mathrm{X} 3 & : & \text { Environment }\end{array}$

HASIL PENELITIAN DAN PEMBAHASAN

Hasil Penelitian 


\section{Tabel 2. Deskripsi Responden}

\begin{tabular}{|c|c|c|c|}
\hline Deskripsi & Keterangan & Total & Persentase (\%) \\
\hline Jenis Kelamin & $\begin{array}{l}\text { Pria } \\
\text { Wanita }\end{array}$ & $\begin{array}{l}62 \\
38\end{array}$ & $\begin{array}{l}62 \\
38\end{array}$ \\
\hline Usia (tahun) & $\begin{array}{l}15-20 \\
21-25 \\
26-30 \\
31-35\end{array}$ & $\begin{array}{l}5 \\
40 \\
37 \\
18\end{array}$ & $\begin{array}{l}5 \\
40 \\
37 \\
18\end{array}$ \\
\hline Pendidikan Terakhir & $\begin{array}{l}\text { SMP } \\
\text { SMA } \\
\text { S1/D3 } \\
\text { Pascasarjana } \\
\text { Lainnya }\end{array}$ & $\begin{array}{l}2 \\
45 \\
48 \\
5 \\
-\end{array}$ & $\begin{array}{l}2 \\
45 \\
48 \\
5 \\
-\end{array}$ \\
\hline Pekerjaan & $\begin{array}{l}\text { Pelajar } \\
\text { Mahasiswa } \\
\text { Pegawai negeri/BUMN } \\
\text { Pegawai swasta } \\
\text { Pengusaha } \\
\text { Wiraswasta } \\
\text { Lainnya }\end{array}$ & $\begin{array}{l}6 \\
41 \\
6 \\
22 \\
15 \\
8 \\
2 \\
\end{array}$ & $\begin{array}{l}6 \\
41 \\
6 \\
22 \\
15 \\
8 \\
2\end{array}$ \\
\hline \multirow{2}{*}{$\begin{array}{l}\text { Mengetahui tentang pasar } \\
\text { modal dan saham }\end{array}$} & $\mathrm{Ya}$ & \multicolumn{2}{|l|}{89} \\
\hline & Tidak & 11 & \\
\hline \multirow{2}{*}{$\begin{array}{l}\text { Memiliki pengalaman } \\
\text { berinvestasi saham/ investasi } \\
\text { online }\end{array}$} & Pernah & \multicolumn{2}{|l|}{59} \\
\hline & $\begin{array}{l}\text { Tidak } \\
\text { Pernah }\end{array}$ & \multicolumn{2}{|l|}{41} \\
\hline
\end{tabular}

(Sumber: Olahan Data, 2019)

Data dari Tabel 1 dari 100 responden penelitian, responden paling banyak adalah: pria (62\%), berusia 21- 25 tahun (40\%), berpendidikan perguruan tinggi S1/D3 (48\%), bekerja sebagai mahasiswa (41\%), mengetahui tentang pasar modal dan saham $(89 \%)$, serta memiliki pengalaman berinvestasi saham/investasi online (59\%). Hasil ini menunjukkan bahwa responden penelitian adalaha pria muda, berpendidikan tinggi, masih berstatus mahasiswa, mengetahui tentang pasar saham serta memiliki pengalaman berinvestasi saham/ investasi online.

$1 \quad$ Analisis Data

\section{$2 \quad$ Uji Kualitas Data, Uji Validitas dan Uji Reliabilitas}

3 Validitas keterkaitan item pertanyaan dalam satu variabel. Untuk menguji valid dan tidaknya pertanyaan yang 4 akan diajukan dengan membandingkan nilai $r$ hitung dibandingkan dengan $r$ table, dengan taraf signifikan 5\% dan 5 jumlah responden sebanyak 150 orang). Reliabilitas adalah indeks yang menunjukkan sejauh mana suatu alat 
pengukur dapat dipercaya atau dapat diandalkan. Bila suatu alat pengukur dipakai dua kali atau lebih untuk mengukur gejala yang sama dan hasilnya relatif konsisten, maka alat pengukur tersebut reliabel. Dengan kata lain reliabilitasnya menunjukkan konsistensi. Tingkat Reliabilitas berdasarkan Alpha (Sugiyono, 2018).

Tabel 3. Uji Validitas dan Reliabilitas

\begin{tabular}{|c|c|c|c|c|c|c|c|}
\hline \multirow{6}{*}{$\begin{array}{l}\text { Variabel } \\
\text { Financial } \\
\text { Literacy } \\
\text { (X1) }\end{array}$} & \multirow{2}{*}{$\begin{array}{l}\text { Indik. } \\
X 1.1\end{array}$} & \multirow{2}{*}{$\begin{array}{l}\text { Item (Variables) } \\
\begin{array}{l}\text { Saya tahu bagaimana } \\
\text { berinvestasi online }\end{array}\end{array}$} & \multicolumn{3}{|c|}{ Correlation (r) } & \multicolumn{2}{|c|}{ Reliabilitas } \\
\hline & & & 0,808 & 0.000 & Valid & \multirow{5}{*}{0.933} & \multirow{5}{*}{$\begin{array}{l}\text { Sangat } \\
\text { Reliable }\end{array}$} \\
\hline & $\mathrm{X} 1.2$ & $\begin{array}{l}\text { Saya tahu tipe-tipe investasi } \\
\text { online }\end{array}$ & 0,943 & 0.000 & Valid & & \\
\hline & $\mathrm{X} 1.3$ & $\begin{array}{l}\text { Saya tahu investasi memiliki } \\
\text { dampak baik dan tidak baik }\end{array}$ & 0,940 & 0.000 & Valid & & \\
\hline & $\mathrm{X} 1.4$ & $\begin{array}{l}\text { Saya tahu konsep investasi } \\
\text { online }\end{array}$ & 0,870 & 0.000 & Valid & & \\
\hline & $\mathrm{X} 1.5$ & $\begin{array}{l}\text { Saya tahu dimana memperoleh } \\
\text { informasi investasi online }\end{array}$ & 0,880 & 0.000 & Valid & & \\
\hline \multirow{5}{*}{$\begin{array}{l}\text { Personal } \\
\text { Interest (X2) }\end{array}$} & $\mathrm{X} 2.1$ & Jaminan Kembali & 0,809 & 0.000 & Valid & \multirow[t]{5}{*}{0.862} & \multirow{5}{*}{$\begin{array}{l}\text { Sangat } \\
\text { Reliable }\end{array}$} \\
\hline & $\mathrm{X} 2.2$ & $\begin{array}{l}\text { Saya mau berinvestasi dalam } \\
\text { pendapatan } \\
\text { kecil }\end{array}$ & 0,924 & 0.000 & Valid & & \\
\hline & $\mathrm{X} 2.3$ & $\begin{array}{l}\text { Saya tahu berinvestasi online } \\
\text { memberikan } \\
\text { pengembalian yang tinggi }\end{array}$ & 0,883 & 0.000 & Valid & & \\
\hline & $\mathrm{X} 2.4$ & $\begin{array}{l}\text { Saya berminant investasi } \\
\text { online jangka panjang }\end{array}$ & 0,766 & 0.000 & Valid & & \\
\hline & $\mathrm{X} 2.5$ & $\begin{array}{l}\text { Saya akan berinvestasi pada } \\
\text { investasi online dan saham } \\
\text { online }\end{array}$ & 0,645 & 0.000 & Valid & & \\
\hline \multirow[t]{5}{*}{$\begin{array}{l}\text { Environment } \\
\text { (X3) }\end{array}$} & $\mathrm{X} 3.1$ & $\begin{array}{l}\text { Politik dan sosial berdampak } \\
\text { pada investasi online }\end{array}$ & 0,753 & 0.000 & Valid & \multirow[t]{5}{*}{0.841} & \multirow{5}{*}{$\begin{array}{l}\text { Sangat } \\
\text { Reliable }\end{array}$} \\
\hline & $\mathrm{X} 3.2$ & $\begin{array}{l}\text { Insentif pajak berpengaruh } \\
\text { terhadap investasi online }\end{array}$ & 0.863 & 0.000 & Valid & & \\
\hline & $\mathrm{X} 3.3$ & $\begin{array}{l}\text { Meningkatnya harga tanah } \\
\text { mendorong saya berinvestasi } \\
\text { online }\end{array}$ & 0,860 & 0.000 & Valid & & \\
\hline & $\mathrm{X} 3.4$ & $\begin{array}{l}\text { Kondisi ekonomi mendorong } \\
\text { saya berinvestasi online }\end{array}$ & 0,735 & 0.000 & Valid & & \\
\hline & $\mathrm{X} 3.5$ & $\begin{array}{l}\text { Orang-orang disekitar saya } \\
\text { mendorong saya berinvestasi } \\
\text { online }\end{array}$ & 0,684 & 0.000 & Valid & & \\
\hline \multirow{5}{*}{$\begin{array}{l}\text { Online } \\
\text { Investment } \\
\text { Interest }(\mathrm{Y})\end{array}$} & Y1.1 & $\begin{array}{l}\text { Saya berminat berinvestasi } \\
\text { online }\end{array}$ & 0,936 & Valid & 0.000 & \multirow[t]{5}{*}{0.972} & \multirow[t]{5}{*}{$\begin{array}{l}\text { Sangat } \\
\text { Reliable }\end{array}$} \\
\hline & Y1.2 & $\begin{array}{l}\text { Saya berminat pada investasi } \\
\text { online jangka panjang }\end{array}$ & 0,954 & Valid & 0.000 & & \\
\hline & Y1.3 & $\begin{array}{l}\text { Saya berminat pada investasi } \\
\text { yang baik }\end{array}$ & 0,969 & Valid & 0.000 & & \\
\hline & Y1.4 & $\begin{array}{l}\text { Saya berminat pada investasi } \\
\text { online yang memberikan } \\
\text { pendapatan }\end{array}$ & 0,937 & Valid & 0.000 & & \\
\hline & Y1.5 & $\begin{array}{l}\text { Saya berminat pada investasi } \\
\text { online yang berisiko tinggi }\end{array}$ & 0,956 & Valid & 0.000 & & \\
\hline
\end{tabular}




\section{Uji Asumsi Klasik}

Untuk menentukan normal tidaknya data pada variabel dependen dilakukan dengan melihat grafik plot normal. Apabila data distribusi normal, maka penyebaran plot akan berada disepanjang garis 45o. Dari grafik plot normal dapat diketahui bahwa penyebaran plot berada di sepanjang garis 45o sehingga dapat disimpulkan bahwa data terdistribusi secara normal. Keterangan diatas dapat dilihat pada gambaran pada gambar berikut.

\section{Uji Normalitas}

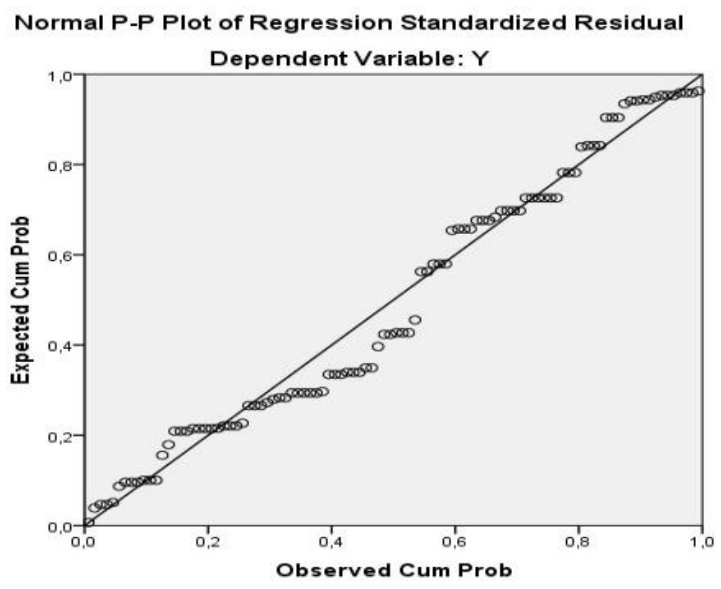

Gambar 1. Uji Normalitas

(Sumber: Olahan Data, 2019)

\section{Uji Heteroskedastisitas}

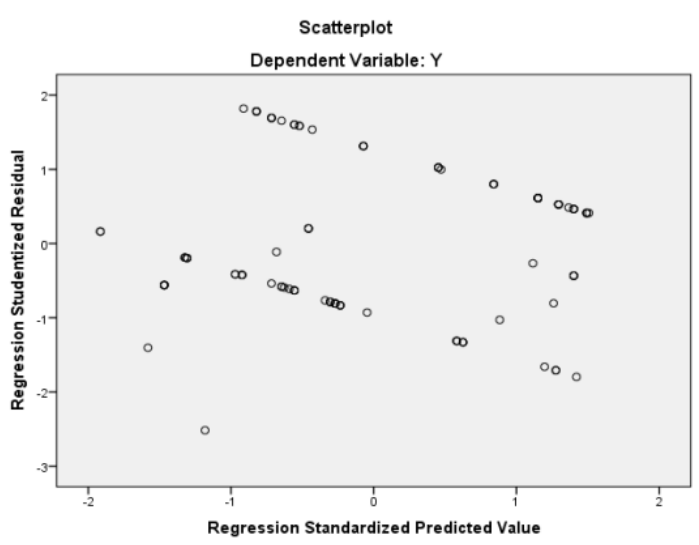

Gambar 2.Uji Heterokedastisitas

(Sumber: Olahan Data, 2019)

Gambar di atas grafik Scatterplot yang ditampilkan untuk uji heterokesdastisitas menampakkan titik-titik yang menyebar secara acak dan tidak ada pola yang jelas terbentuk serta dalam penyebaran titik-titik tersebut menyebar dibawah dan diatas angka 0 pada sumbu Y. Hal tersebut mengidentifikasikan tidak terjadinya heterokesdastisitas pada model regresi, sehingga model regresi layak dipakai untuk memprediksi variabel Y. 


\section{Analisis Regresi Berganda}

Analisis regresi berganda digunakan untuk mengetahui seberapa besar pengaruh variabel bebas dalam penelitian ini memiliki pengaruh terhadap variabel terikatnya. Perhitungan analisis data dalam penelitian ini menggunakan analisis statistik manual dan pengolahan data dengan SPSS 23 . Nilai hasil perhitungan adalah seperti pada tabel berikut ini.

\section{Tabel 4. Koefisien Regresi Uji t, Uji F}

\begin{tabular}{lllll}
$\begin{array}{l}\text { Regression } \\
\text { Coeef. }(\mathbf{b})\end{array}$ & Std Er & $\mathbf{t}$ (count) & Sig. & Desc \\
\hline 8,770 & 3,498 & 2,507 &, 004 & \\
, 501 &, 105 & 4,773 &, 000 & Sig \\
, 163 &, 193 & 2,747 &, 004 & Sig \\
, 146 &, 109 & 2,422 &, 004 & Sig \\
\hline
\end{tabular}

\begin{tabular}{lcc}
\hline Konstanta & 8,770 & 3,498 \\
Financial Literacy $(\mathrm{X} 1)$ &, 501 &, 105 \\
Personal Interest (X2) &, 163 &, 193 \\
Environment (X3) &, 146 &, 109 \\
\hline \multicolumn{3}{c}{ Y $=\mathbf{8 , 7 7 0 + 0 , 5 0 1 ~ X 1 ~ + ~ 0 , 1 6 3 ~ X 2 ~}$} \\
\hline R & $=$ & 0.505 \\
R Square & $=$ & 0.255 \\
F count & $=$ & 10,936 \\
t table & $=$ & 2,008 \\
Sig. F & $=$ & 0.000 \\
n & $=$ & 100 \\
$\square$ & $=$ & $0.05(5 \%)$
\end{tabular}

(Sumber: Olahan Data, 2019)

Bentuk persamaan regresi dapat di tulis sebagai berikut :

$$
\mathrm{Y}=\mathbf{8 , 7 7 0}+\mathbf{0 , 5 0 1} \mathrm{X1}+\mathbf{0 , 1 6 3} \mathrm{X} 2+0,146 \mathrm{X3}+\mathrm{e}
$$

Hasil persamaan regresi berganda tersebut di atas memberikan pengertian

bahwa:

1. Konstanta a sebesar $-1,550$ memberikan pengertian bahwa jika variabel Financial Literacy (X1), Personal Interest (X2), Environment (X3) tidak berubah maka besarnya Minat Berinvestasi Online adalah 8,770.

2. Untuk variabel Financial Literacy (X1) koefisien regresinya adalah positif, hal ini dapat diartikan apabila Financial Literacy (X1) semakin meningkat, maka Minat Berinvestasi Online akan meningkat sebesar 0,501 dengan asumsi variable lainnya tetap atau konstan. Variabel Financial Literacy merupakan variabel yang paling berdampak terhadap Minat Berinvestasi Online dibandingkan variabel lainnya dalam penelitian ini.

3. Untuk variabel Personal Interest (X2) koefisien regresinya adalah positif, hal ini dapat diartikan apabila Personal Interest (X2) semakin meningkat, maka Minat Berinvestasi Online akan meningkat sebesar 0,163 dengan asumsi variable lainnya tetap atau konstan. Variabel Personal Interest (X2) merupakan variabel yang kedua yang berdampak terhadap Minat Berinvestasi Online dalam model penelitian ini.

4. Untuk variabel Environment (X3) koefisien regresinya adalah positif, hal ini dapat diartikan apabila Environment (X3) semakin meningkat, maka Minat Berinvestasi Online akan meningkat sebesar 0,146 dengan asumsi variable lainnya tetap atau konstan. Variabel Environment (X3) merupakan variabel yang terakhir yang berdampak terhadap Minat Berinvestasi Online dalam model penelitian ini.

\section{Pembahasan}

Dengan menggunakan bantuan program SPSS maka hasil Fhitung dapat dilihat pada Tabel 3. Hasil Fhitung $=10,936$ dan Ftabel $=2,400$. Jadi ditemukan bahwa Fhitung $>$ Ftabel dengan tingkat signifikansi sig $\mathrm{F}=0,0000<0,05$, ini menunjukan bahwa $\mathrm{H} 0$ ditolak dan $\mathrm{Ha}$ diterima. Dengan demikian hasil uji $\mathrm{F}$ menyatakan bahwa H0 ditolak dan Ha diterima, artinya Financial Literacy (X1), Personal Interest (X2), Environment (X3) secara simultan berpengaruh signifikan terhadap Minat Berinvestasi Online. Dari hasil uji 
pada Tabel 3 dapat dilihat bahwa variabel Personal Interest (X2) thitung $=2,747>$ tabel $=2,008$ dan tingkat signifikan 0,004 < 0,05, maka dapat disimpulkan bahwa $\mathrm{Ha}$ diterima dan $\mathrm{H} 0$ ditolak atau Personal Interest (X2) berpengaruh signifikan terhadap Minat Berinvestasi Online. Dari hasil uji t pada Tabel 3 dapat dilihat bahwa variabel Environment $(\mathrm{X} 3)$ thitung $=2,422>$ t tabel $=2,008$ dan tingkat signifikan 0,004 < 0,05, maka dapat disimpulkan bahwa $\mathrm{Ha}$ diterima dan $\mathrm{H} 0$ ditolak atau Environment (X3) berpengaruh signifikan terhadap Minat Berinvestasi Online. Dari hasil uji t pada Tabel 3 dapat dilihat bahwa variabel Financial Literacy (X1) thitung $=4,773>$ ttabel $=2,008$ dan tingkat signifikan $0,000<0,05$, maka dapat disimpulkan bahwa $\mathrm{Ha}$ diterima dan H0 ditolak atau Financial Literacy (X1) berpengaruh signifikan terhadap Minat Berinvestasi Online.

Berdasarkan hasil perhitungan dengan menggunakan bantuan program SPSS seperti yang ada pada Tabel 5 dapat dilihat bahwa nilai (R) yang dihasilkan adalah sebesar 0,505 artinya mempunyai hubungan yang kuat. Nilai $\mathrm{R}$ square adalah 0,255 atau $25,5 \%$ Artinya pengaruh semua variable bebas yaitu: Financial Literacy (X1), Personal Interest (X2), Environment (X3) terhadap variable independent Minat Berinvestasi Online adalah sebesar 25,5\% dan sisanya sebesar 0,745 atau $74.5 \%$ dipengaruhi variable-variabel lain di luar penelitian ini.

Hasil penelitian ini memiliki persamaan dengan penelitian sebelumnya (Azhar dkk., 2017; Susanti dkk., 2018) dimana dalam penelitian sebelumnya tersebut terdapat beragam faktor yang mempengaruhi minat berinvestasi termasuk berinvestasi secara online. Diantaranya adalah Financial Literacy, Personal Interest, Environment.

\section{PENUTUP}

\section{Kesimpulan}

Hasil penelitian dan pembahasan menunjukkan bahwa:

1. Terdapat pengaruh Financial Literacy, Personal Interest, dan Environment terhadap minat berinvestasi online.

2. Terdapat pengaruh Financial Literacy terhadap minat berinvestasi online.

3. Terdapat pengaruh Personal Interest terhadap minat berinvestasi online.

4. Terdapat pengaruh Environment terhadap minat berinvestasi online.

\section{Saran}

Saran dari penelitian ini sebagai berikut:

1. Bagi peneliti selanjutnya disarankan menggunakan sampel yang lebih besar sehingga hasil lebih memperkuat hasil temuan penelitian ini.

2. Bagi peneliti selanjutnya disarankan melakukan penelitian minat investasi online di lokasi dan objek lain di luar Manado. 


\section{DAFTAR PUSTAKA}

Arikunto, S. (2012). Prosedur Penelitian Suatu Pendekatan Praktik. Jakarta: Rineka Cipta.

Azhar, Z., Azilah, N., \& Syafiq, A. (2017). Investment Awareness Among Young Generation. Advances in Economics, Business and Management Research, 36(1), 126-135.

Bandi, \& Hartono, J. (2000). Perilaku reaksi harga dan volume perdagangan saham terhadap pengumuman deviden. JRAI, 3(2).

Ghozali, I. (2013). Aplikasi Analisis Multivariate dengan Program SPSS. Semarang: Badan Penerbit Universitas Diponegoro.

Herlianto, D. (2013). Manajemen Investasi plus Jurus Mendeteksi Investasi Bodong. Yogyakarta: Gosyen Publishing.

Ikatan Akuntan Indonesia. (2015). Standar Akuntansi Keuangan ETAP. Jakarta: Ikatan Akuntan Indonesia (IAI). Kamarudin, A. (2009). Dasar-Dasar Manajemen Investasi dan Portofolio. Jakarta: Rineka Cipta.

Pajar, R. C. (2017). Pengaruh Motivasi Investasi Dan Pengetahuan Investasi Terhadap Minat Investasi Di Pasar Modal Pada Mahasiswa Fe Uny. Jurnal Profita, 1(1), 1-16.

Salim, H. S., \& Sutrisno, B. (2008). Hukum Investasi di Indonesia. Jakarta: Raja Grafindo Persada.

Sanicola, L. (2017, Februari 13). What is FinTech? [News]. Diambil 1 Juni 2019, dari HuffPost website: https://www.huffpost.com/entry/what-is-fintech_b_58a20d80e4b0cd37efcfebaa

Schueffel, P. (2016). Taming the Beast: A Scientific Definition of Fintech. Journal of Innovation Management, $4(4), 32-54$.

Soemitra, A. (2014). Masa Depan Pasar Modal Syariah di Indonesia. Jakarta: Prenada Media Group. Sugiyono. (2018). Metode Penelitian Kuantitatif. Bandung: Alfabeta.

Sukardi. (2003). Bimbingan dan Penyuluhan Belajar di Sekolah. Bandung: Usaha Nasional.

Susanti, S., Hasan, M., Ahmad, M. I. S., \& Marhawati. (2018). Faktor-Faktor yang Mempengaruhi Minat Mahasiswa Berinvestasi di Galeri Investasi Universitas Negeri Makassar. Dipresentasikan pada Prosiding Seminar Nasional Pendidikan Ekonomi 2018, Makassar.

Tandelilin, E. (2012). Analisis Investasi dan Manajemen Portofolio. Teori dan Aplikasi. Yogyakarta: BPFE.

Tulung, J. E., Saerang, I. S., \& Pandia, S. (2018). The influence of corporate governance on the intellectual capital disclosure: a study on Indonesian private banks. Banks and Bank Systems, 13(4), 61-72.

Tulung, J. E., \& Ramdani, D. (2018). Independence, size and performance of the board: An emerging market research. Corporate Ownership \& Control, 15(2-1), 201-208.

Tulung, J. E., \& Ramdani, D. (2015). The Influence of Top Management Team Characteristics on BPD Performance. International Research Journal of Business Studies, 8(3), 155-166.

Winkel, W. S. (2009). Psikologi Pengajaran. Jakarta: PT. Gramedia Pustaka. 